\title{
Pemetaan Suhu Permukaan Anomali Panas Bumi Daerah Gunung Ciremai Menggunakan Data Inframerah Termal Landsat 8
}

\author{
Syatiya Mirwanda ${ }^{{ }^{*}}$, Fatiha Salsabiila ${ }^{1}$, Regita Pramesti ${ }^{1}$, Annida Rifqoh Zakiyyah ${ }^{1}$, Muhamad \\ Rizki Tuelzar ${ }^{2}$ \\ ${ }^{1}$ Jurusan Teknik Geofisika, Fakultas Teknik, Universitas Lampung, Jl. Prof. Dr. Ir. Sumantri Brojonegoro, Bandar Lampung, \\ Lampung 35141 \\ ${ }^{2}$ Program Studi Teknik Sistem Energi, Institut Teknologi Sumatera, Jl. Terusan Ryacudu, Desa Way Hui, Jati Agung, Lampung \\ Selatan, Lampung 35365
}

Dikirim:
14 Oktober 2021
Direvisi:
19 November 2021
Diterima:
26 November 2021
^Email Korespondensi:
syatiya03032000@gmail.com
20) (1) (2)

Abstrak: Prospek geotermal di daerah Timur Ciremai berada pada aktivitas vulkanik aktif namun pencarian prospek panas bumi di area ini mengabur akibat adanya kontras antara batuan vulkanik dengan batuan sedimen. Penelitian ini mencoba mengidentifikasi area potensial panas bumi berdasarkan suhu permukaan menggunakan metode pengindraan jauh. Data yang digunakan berupa citra satelit Landsat 8 yang sudah mempunyai sensor termal yang disebut Thermal Infrared Sensor (TIRS) pada pita sensor 10 dan 11 yang dikombinasikan dengan NDVI. Hasil analisis NDVI menunjukkan bahwa daerah penelitian memiliki vegetasi dan permukaan berupa air atau awan yang lebih banyak memantulkan gelombang cahaya tampak dibandingkan gelombang infrared dengan nilai NDVI -0,75 - 0,88. Hasil analisis LST dapat diketahui bahwa suhu permukaan pada daerah tersebut memiliki nilai dalam rentang $15^{\circ} \mathrm{C}-31^{\circ} \mathrm{C}$. Area yang memiliki tingkat LST tinggi di antara tingkat LST yang rendah dapat diperkirakan sebagai area yang memiliki anomali. Hal ini bersesuaian dengan kerapatan vegetasi pada area tersebut yang tinggi sehingga seharusnya besar suhu permukaannya rendah bukan sebaliknya. Berdasarkan integrasi dengan data manifestasi di lapangan, maka dapat di pastikan bahwasanya terdapat beberapa anomali panas bumi pada arah tenggara dari Gunung Ciremai.

Kata kunci: Citra Satelit, Landsat 8, Panas Bumi, Suhu Permukaan, NDVI

\begin{abstract}
The geothermal prospect in the East Ciremai area is in active volcanic activity but the search for geothermal prospects in this area is blurred due to the contrast between volcanic rocks and sedimentary rocks. This study tries to identify potential geothermal areas based on surface temperature using remote sensing methods. The data used is in the form of Landsat 8 satellite imagery which already has a thermal sensor called the Thermal Infrared Sensor (TIRS) on sensor bands 10 and 11 combined with NDVI. The results of the NDVI analysis show that the research area has vegetation and a surface in the form of water or clouds that reflect more visible light waves than infrared waves with an NDVI value of $-0.75-0.88$. The results of the LST analysis can be seen that the surface temperature in the area has a value in the range of $15^{\circ} \mathrm{C}-31^{\circ} \mathrm{C}$. Areas with high LST levels among Iow LST levels can be estimated as areas with anomalies. This is in accordance with the high density of vegetation in the area so that the surface temperature should be low, not the other way around. Based on the integration with the manifestation data in the field, it can be ascertained that there are several geothermal anomalies in the southeast direction of Mount Ciremai.

Keywords: Geothermal, Landsat 8, Land Surface Temperature, NDVI, Satellite Image,
\end{abstract}

\section{PENDAHULUAN}

Gunung Ciremai merupakan salah satu gunung api yang terletak di Pulau Jawa. Daerah Gunung Ciremai memiliki potensi panas bumi dengan beberapa prospek seperti prospek Sangkanhurip, prospek Ciniru, dan prospek Pajambon. Prospek Sangkanhurip memiliki luas reservoir sebesar $2 \mathrm{~km}^{2}$ dengan kisaran suhu berada pada temperatur 140 ${ }^{\circ} \mathrm{C}$ dan ketebalan reservoir sebesar $1,25 \mathrm{Km}$. Berdasarkan hasil perhitungan dengan metode volumetrik dapat diperkirakan prospek ini memiliki cadangan sebesar 25 MW. Prospek Ciniru memiliki luas reservoir sebesar $8.5 \mathrm{~km}^{2}$ dengan kisaran suhu pada temperatur $140^{\circ} \mathrm{C}$ dan ketebalan reservoir sebesar $2 \mathrm{Km}$ (hasil modeling data MT). Berdasarkan hasil perhitungan dengan metode volumetrik dapat diperkirakan prospek ini memiliki cadangan sebesar 75 MW. Prospek Pajambon memiliki luas reservoir sebesar $10 \mathrm{~km}^{2}$ dengan kisaran suhu pada temperatur $140{ }^{\circ} \mathrm{C}$. Berdasarkan hasil perhitungan dengan metode volumetrik dapat diperkirakan prospek ini memiliki cadangan sebesar 135 MW (Pratomo, 2008; Samodra, 2008).

Prospek geotermal di daerah Timur Ciremai berada pada aktivitas vulkanik aktif dengan heatsource berupa intrusi andesit pada batuan sedimen tersier. Namun pencarian prospek panas bumi di area ini mengabur akibat adanya kontras antara batuan vulkanik dengan batuan sedimen. Indikasi sistem Hidrotermal berada pada barat Ciremai didapatkan dari hasil pengolahan data sounding. Ditemukan pula anomali yang tinggi di timur hingga timur laut lereng Gunung Ciremai yang didapatkan dari data sebaran merkuri soil dan data 
sebaran $\mathrm{CO}^{2}$ soil. Prospek panas bumi di Indonesia tersebar di beberapa daerah terutama daerah dengan adanya aktivitas vulkanisme. Namun, pada daerah Gunung Ciremai ini terjadi pertentangan mengenai rencana eksplorasi panas bumi yang ditolak oleh masyarakat akibat adanya isu-isu yang mengangkat dampak negatif dari eksplorasi panas bumi. Padahal sejatinya, energi panas bumi merupakan energi yang terbilang ramah lingkungan dan juga terbarukan terutama untuk pembangkit listrik dibandingkan dengan sumber lainnya seperti bahan bakar minyak serta didukung dengan keberadaan potensi panas bumi Indonesia yang besar. Selain itu, panas bumi daerah Gunung Ciremai ini juga dapat membuka potensi wisata, peternakan, dan agrobisnis yang mana daerah Gunung Ciremai ini memiliki luas wilayah kerja panas bumi hingga $38.560 \mathrm{Ha}$.

Untuk mengidentifikasi karakteristik suatu objek di permukaan bumi, dapat digunakan teknologi penginderaan jauh sehingga tidak perlu dilakukan peninjauan langsung ke lapangan. Penginderaan jauh ini memiliki manfaat salah satunya dalam memvisualisasikan persebaran suhu permukaan bumi dengan menggunakan pengolahan berupa Land Surface Temperature (LST), Normalized Difference Vegetation Index (NDVI) dan delineasi kelurusan. Dengan metode overlay - Analitycal Hierarchy Process (AHP), data lokasi mata air panas dan batuan ubahan, dan perhitungan potensi energi panas bumi, dapat mendukung pemetaan secara spesifik. Artikel ini bertujuan untuk mengetahui sebaran area potensi panas bumi menggunakan citra Landsat 8 yang telah memiliki sensor Thermal Infrared Sensor (TIRS) pada band 4, 5, 10 dan 11 di kawasan Gunung Ciremai dan mengetahui nilai signifikansi suhu hasil pengolahan LST dan validasi lapangan.

\section{BAHAN DAN METODE PENELITIAN \\ 2.1. Lokasi Penelitian}

Gunung Ciremai adalah gunung api soliter tertinggi di Jawa Barat dengan puncak tertingginya yaitu 3.078 mdpl. Gunung Ciremai ini termasuk ke dalam Kawasan Taman Nasional Gunung Ciremai (TNGC) yang terletak di wilayah Kabupaten Kuningan seluas 8.792,21 Ha (59,24\%), Kabupaten Majalengka seluas $6.031,26 \mathrm{Ha}(40,64 \%)$ dan Kabupaten Cirebon seluas $17,83 \mathrm{Ha}(0,12 \%)$ dengan batas wilayah secara administratif yaitu sebelah utara adalah Kecamatan Dukupuntang Kabupaten Cirebon, sebelah Timur adalah Kabupaten Kuningan, sebelah Selatan adalah kecamatan Darma Kabupaten Kuningan, dan sebelah Barat adalah Kabupaten Majalengka.

Gunung Ciremai $( \pm 3.078 \mathrm{~m}$ ) yang terletak pada 106059' Bujur Timur dan 6 047' Lintang Selatan adalah sebuah gunungapi strato tipe A (pernah meletus setelah tahun 1600). Secara fisiografi, Gunung Ciremai merupakan yang terpisah dari serangkaian klaster gunung api pulau Jawa karena letaknya berada pada bagian utara pulau Jawa (gunungapi soliter) (Gambar 1). Secara administratif, Gunung Ciremai masuk ke dalam wilayah Kabupaten Ciremai, Provinsi Jawa.

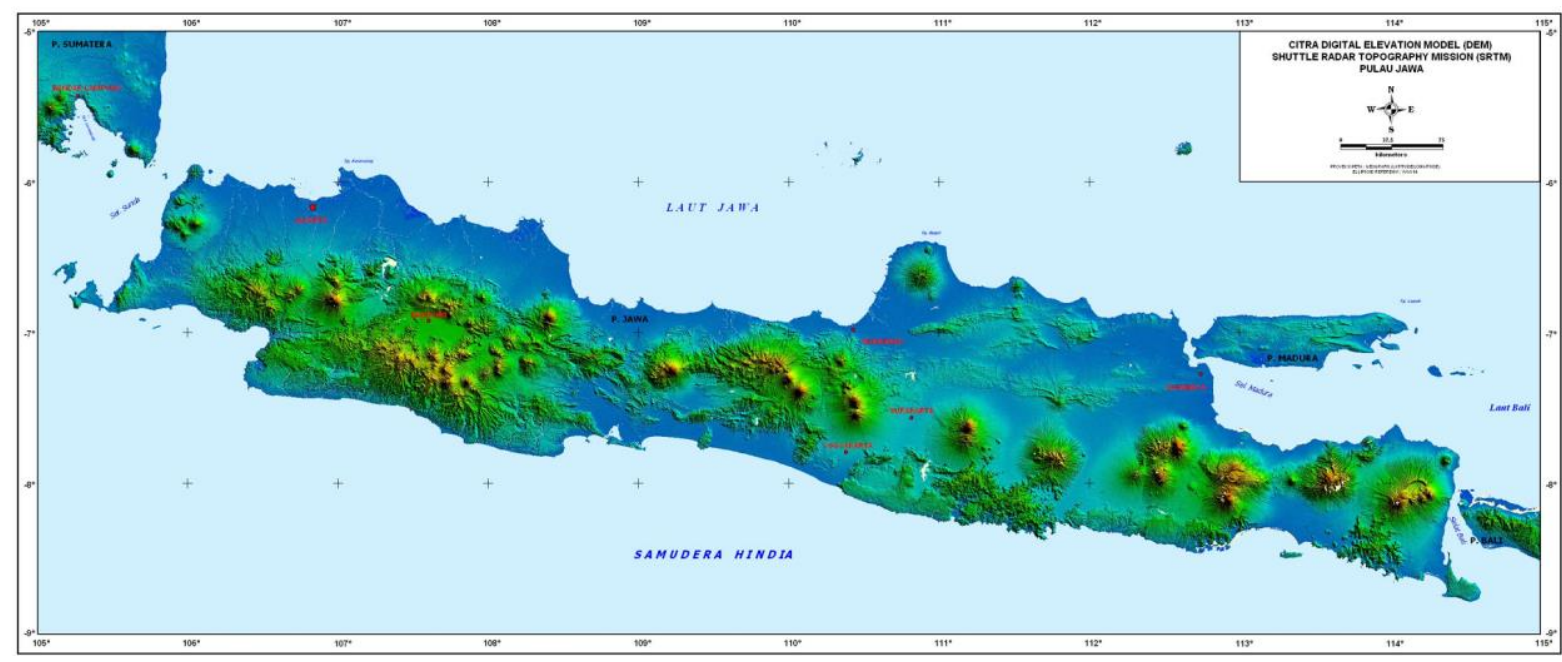

Gambar 1. Posisi Gunung Ciremai terhadap rentetan gunungapi aktif di pulau Jawa, berdasarkan Citra Digital Elevation Model dan Shuttle Radar Topographic Mission (SRTM) Pulau Jawa (Pratomo, 2008).

\subsection{Geologi daerah penelitian}

Gunungapi Ciremai berada di atas formasi batuan sedimen berumur MioPliosen (Hanang S., 2008). Pada wilayah tersebut terdapat sesar dengan arah barat laut-tenggara (Gambar 2). Erupsi terakhir Gunung Ciremai terjadi pada 24 Juni 1937 hingga 7 Januari 1938 (Kusumadinata, 1971). Akibat aktifnya gunungapi ini, wilayah sekitar Gunung Ciremai relatif subur sehingga dipadati oleh pemukiman penduduk.
Pada peta persebaran gunungapi Kuarter di Pulau Jawa, Gunung Ciremai terletak di luar dari jalur gunungapi aktif lainnya pada deretan tengah Pulau Jawa. Gunung api Ceremai tergolong gunung api terisolir yang dapat dilihat dari posisi gunung itu sendiri yang masih aktif dan jauh dari kelompok gunung lainnya. Jalur gunungapi aktif tipe strato di pulau Jawa kebanyakan menghasilkan batu andesit piroksen serta basal dengan kandungan alumina 
tinggi yang dikaji berdasarkan petrologi juga geokimia (Samodra, 2008).

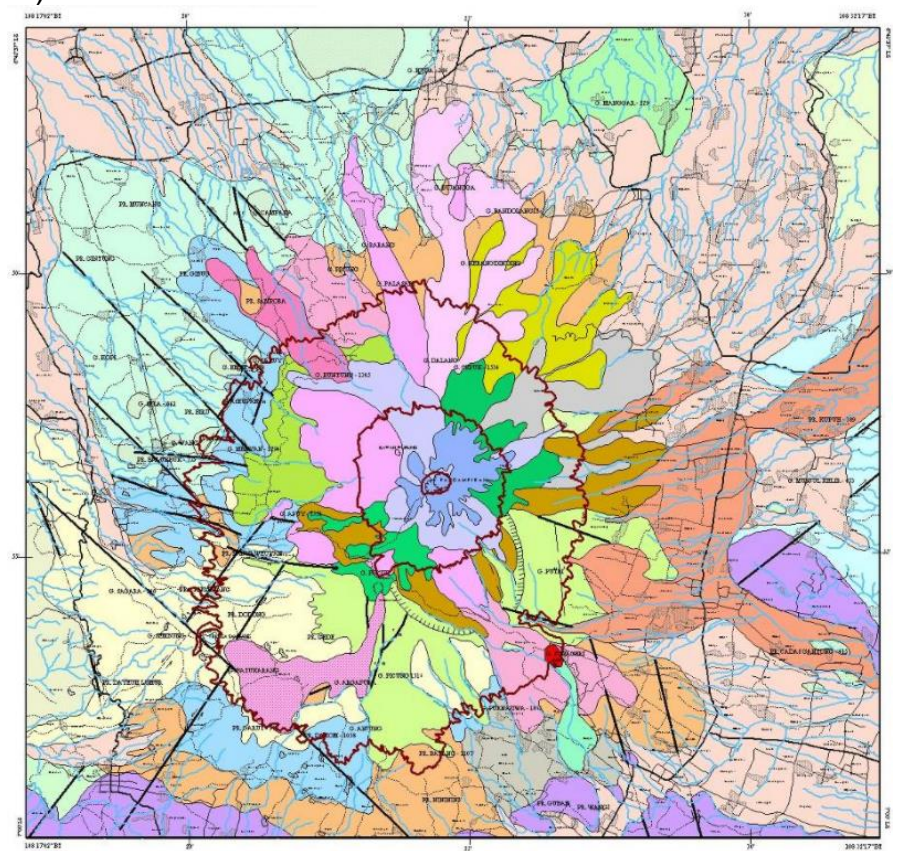

Gambar 2. Peta Geologi Gunungapi Ciremai (Situmorang dkk., 1995).

Dikaji dari litologi batuan yang ada pada daerah gunungapi Ceremai, dapat diketahui terdiri dari lahar, batupasir tuf dan breksi gunungapi. Pada bagian tenggara dari gunung tepatnya di dekat Kuningan endapannya membentuk permukaan dengan morfologi yang lebih kasar dan lebih tererosi daripada morfologi yang baru terbentuk oleh gunungapi muda Ceremai. Untuk dapat mengenal litologi tersebut di lapangan, dapat dilihat dari sifat bongkahan andesit dan basal yang ada pada lapisan tanah berwarna kuning kecokelatan di daerah itu. Sebagian dari batuan beku yang terdapat pada wilayah ini merupakan batuan dengan endapan lahar tua dan breksi gunungapi, kemudian sebagian lagi dapat ditemukan sebagai potongan lava. Hal ini teridentifikasi karena terdapat aliran lava tua yang tersingkap di sekitar Desa Tarikolot yang memiliki struktur andesit hornblenda. Dimana batuan tersebut mempunyai bentuk lembaran yang disebabkan karena adanya kekar melembar.

Lava pada batuan gunungapi Ceremai muda cenderung bersifat andesit basaltik, yang memperlihatkan struktur seperti aliran, seperti yang diketahui dimana batuan gunungapi Ciremai muda ini terdiri dari lava dan breksi gunungapi. Untuk breksi gunungapi sendiri tersusun dari komponen andesit dan basal yang kemudian membentuk permukaan daerah dengan morfologi perbukitan rendah atau permukaan yang menggelombang. Lapisan penutup pada daerah ini merupakan hasil pelapukan batuan yang tebal berwarna kelabu, coklat, kuning dan kemerahan. Hal ini dibuktikan dengan ditemukannya batupasir tuf yang berlapis tebal di daerah tersebut.

Hasil dari letusan Gunung Ciremai yang bersifat eksplosif menghasilkan breksi gunungapi sedangkan letusan yang bersifat effusif menghasilkan endapan lava yang dapat diidentifikasi sejak awal Kuarter yang kemudian menindih batuan yang lebih dasar yang lebih tua di daerah ini yang berumur Miosen Tengah hingga Plistosen.

\subsection{Penginderaan jauh dengan citra Landsat 8}

Citra satelit Landsat adalah salah satu dari satelit penginderaan jauh hasil dari pengumpulan data satelit yang mengeluarkan potret wilayah yang cukup luas dengan sistem pengolahan data yang dapat dipahami manusia dengan mudah, sehingga hingga saat ini perkembangan dari citra Landsat sendiri terus meningkat dan sangat berguna dalam kehidupan manusia. Dengan adanya satelit Landsat Data Continuity Mission (LDCM) atau juga dinamakan dengan Landsat 8 sekarang lebih banyak lagi data yang dapat diperoleh dengan keakuratan yang sangat bagus dibanding dengan sebelumnya yaitu Landsat 7 ETM+ (Dianovita \& Mahendra, 2014; Agung dkk., 2017).

Landsat 8 dibuat untuk membawa sensor pencitra Operational Land Imager (OLI) yang mempunyai pita sensor biasa disebut dengan band (Darmawan dkk., 2020; Farras dkk., 2017; Gemitzi dkk., 2021). Terdapat satu band inframerah dekat dan tujuh band tampak reflektif, yang meliput panjang gelombang yang dipantulkan oleh objekobjek di permukaan Bumi. Resolusi untuk citra yang dihasilkan adalah 30 meter sama dengan Landsat sebelumnya. Terdapat juga sensor pencitra temperatur yaitu Thermal Infrared Sensor (TIRS) yang menghasilkan data untuk band inframerah termal yang sama sekali tidak dicitrakan oleh OLI (Sitanggang, 2013).

Mengoreksi kesalahan (error) yang disebabkan karena pergerakan satelit ketika mengorbit bumi menjadi alasan untuk dilakukannya koreksi DOI: https://doi.org/10.23960/jgrs.2021.v2i2.64 
geometrik yang diperlukan dalam analisis citra satelit Landsat 8. Setiap data digital dari remote sensing satelit selalu mempunyai kesalahan geometrik (systematic and unsystematic error). Kesalahan geometrik tersebut dapat dilakukan koreksi yaitu dengan menggunakan variabel yang terdapat dalam data sensor serta pita sensornya. Dalam koreksi geometrik dikenal dua jenis metode yaitu rektifikasi dan orthorektifikasi. Rektifikasi adalah sebuah proses koreksi dengan menyesuai dengan koordinat pada GPS, kemudian peta atau citra lainnya yang sebelumnya sudah dikoreksi. Sedangkan orthorektifikasi merupakan sebuah proses koreksi geometrik dengan menggunakan data elevasi serta informasi posisi dari satelit (Candra \& Santi, 2011). Sebelum dilakukan koreksi geometrik, dilakukan terlebih dahulu melalui proyeksi peta. dibutuhkan penyamaan posisi antara satu citra dengan citra lainnya dengan sistem koordinat DMS (Degree Minute Second) dalam WGS84 (Supriatna \& Sukartono, 2002).

Normalized Dfference Vegetation Index atau disingkat NDVI merupakan nilai kerapatan dari vegetasi yang didapatkan dari data pantulan radiasi serta kecerahan (brightness) yang ditangkap oleh sensor satelit. Dengan mengetahui indeks vegetasi suatu wilayah banyak hal yang dapat dilakukan, proses ini dilakukan dengan membandingkan antara tingkat kecerahan band cahaya merah (red) dengan band inframerah dekat (near infrared).

\subsection{Tahapan pengolahan data}

Pengolahan yang dilakukan dapat dijabarkan seperti pada Gambar 3 di bawah ini.

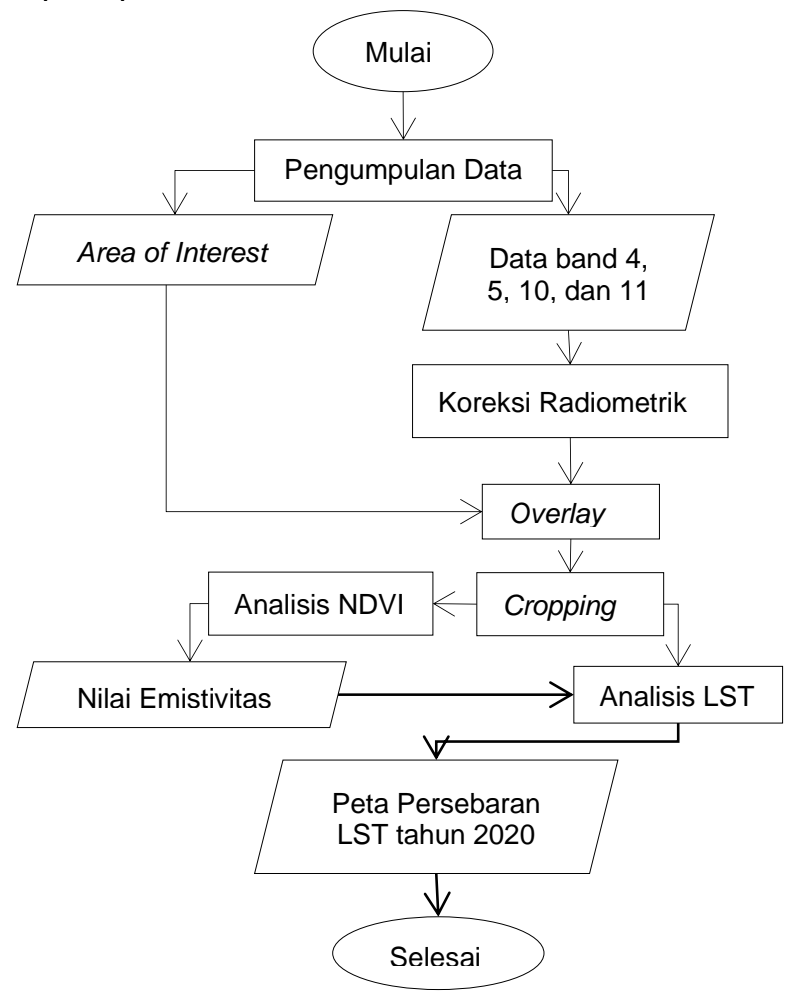

Gambar 3. Diagram alir penelitian potensi panas bumi daerah Gunung Cermai menggunakan data Landsat 8
Landsat LST tidak keluar sebagai produk yang langsung siap digunakan, dan dapat dihitung pada resolusi spasial $30 \mathrm{~m}$ berdasarkan data dari band termal yaitu band 10 (Avdan \& Jovanovska, 2016; Sukendar dkk., 2016).

Secara umum proses yang dilakukan untuk mendapatkan hasil berupa peta persebaran suhu permukaan bumi di daerah penelitian adalah pengolahan kerapatan vegetasi menggunakan metode NDVI dan pengolahan suhu permukaan bumi metode LST (Land Surface Temprature). Tahap awal dari pengolahan ini adalah melakukan koreksi radiometrik dan pemotongan citra. Koreksi radiometrik digunakan untuk memperbaiki kesalahan yang terjadi pada data citra yang disebabkan oleh efek atmosfer bumi. Koreksi ini bisa dilakukan dengan menggunakan rumus sebagai berikut.

$$
\rho \lambda=\frac{M_{\rho} Q_{c a l}+A_{\rho}}{\sin \theta}
$$

$$
\begin{array}{ll}
\rho \lambda & =\text { Reflektasnsi Planetary Spectral } \\
M_{\rho} & =\text { Nilai Reflektan MULT_BAND_X dimana X } \\
& \text { adalah nomor band } \\
Q_{c a l} & =\text { Band yang akan dikoreksi } \\
A_{\rho} & =\text { Nilai reflektan ADD_BAND_X dimana X } \\
& \text { adalah nomor band } \\
\theta & =\text { sudut elevasi matahari }
\end{array}
$$

Pemotongan citra (cropping) dilakukan untuk menyesuaikan citra dengan area yang menjadi objek penelitian. Pada bagian ini kita dapat menghilangkan hambatan seperti keberadaan awan di daerah penelitian. Pengolahan selanjutnya dilakukan dengan menggunakan metode NDVI yang dihitung dari Landsat 8 Band 4 (RED) dan Band 5 (NIR) dengan rumus.

$$
N D V I=\frac{N I R-R E D}{N I R+R E D}
$$

Setelah itu, pancaran dari band 10 yang telah dikonversi kemudian dikonversi lagi ke Brightness Temperature (BT). Untuk memperoleh perkiraan LST, emissivitas tanah atau Land Surface Emissivity (LSE) harus diketahui. Estimasi LSE membutuhkan proporsi vegetasi (Pv) untuk mengetahuinya, dapat dihitung dari persamaan berikut:

$$
P_{v}=\left(\frac{N D V I-N D V I_{\min }}{N D V I_{\max }+N D V I_{\min }}\right)^{2}
$$

Dimana NDVImax, mengacu pada permukaan vegetasi sepenuhnya dan NDVImin sesuai dengan tanah kosong. Selanjutnya, LSE $(\varepsilon \lambda)$ yang dihitung secara kondisional menggunakan rumus berikut (Skoković dkk., 2014).

$$
L S E=\varepsilon \lambda=0.004 P_{v}+0.986
$$


Akhirnya, LST dihitung sebagai emisivitas suhu permukaan tanah yang dikoreksi Ts menggunakan rumus berikut (Avdan \& Jovanovska, 2016).

$$
T_{S}=\frac{B T}{1+\left[\left(\frac{\lambda B T}{\rho}\right) \ln \varepsilon \lambda\right]}
$$

Ts adalah singkatan dari LST dalam derajat Celsius, BT adalah Suhu Kecerahan dari Persamaan (2). Kemudian $\varepsilon \lambda$ merupakan emisivitas suhu permukaan vegetasi pada persamaan (4). $\rho$ pada persamaan (5) didapat dari:

$$
\rho=h \frac{c}{\sigma}=1.438 \times 10^{-2} \mathrm{mK}
$$

di mana $\sigma=1,38 \times 10^{-23} \mathrm{~J} / \mathrm{K}$, adalah konstanta Boltzmann, $h=6,626 \times 10^{-34} \mathrm{Js}$, adalah konstanta Planck dan $c=2,998 \times 10^{8} \mathrm{~m} / \mathrm{s}$, adalah kecepatan cahaya.

\subsection{Bahan dan Peralatan}

Bahan dan peralatan yang digunakan pada penelitian ini antara lain:

1. Data band 4, 5, 10, dan 11 citra Landsat 8 akuisisi pada tanggal 9 September 2020

2. Perangkat keras berupa laptop dengan spesifikasi:

a. Merek dan tipe : Acer Aspire V5-471

b. Tipe prosesor :Prosesor Intel(R) Core(TM) i3-2365M CPU @1.40GHz

c. Spesifikasi RAM : 4 GB

d. Sistem Operasi : Windows 7 Ultimate Pro 32-bit.

3. Perangkat lunak yang digunakan untuk pengolah citra yaitu ArcGIS 10.3.

\section{HASIL DAN PEMBAHASAN}

Citra satelit pada dasarnya menggunakan pantulan gelombang elektromagnetik yang diarahkan ke suatu objek. Sumber gelombang elektromagnetik ini berasal dari sinar matahari sehingga kondisi atmosfer sangat mempengaruhi hasil dari rekaman data citra. Untuk mendapatkan data citra yang baik, maka harus menggunakan citra dengan tutupan awan yang sangat sedikit (0-5 $\%$ ). Citra satelit yang sering digunakan untuk ilmu kebumian salah satunya adalah Landsat. Citra Landsat mampu membaca suhu permukaan dengan akurasi tinggi. Suhu permukaan yang terekam oleh citra dipengaruhi oleh karakteristik objek di muka bumi dimana memancarkan radiasi gelombang elektromagnetik yang bervariasi. Suhu permukaan berbanding terbalik dengan elevasi dimana semakin tinggi elevasinya maka suhu permukaan akan semakin rendah. Bila terjadi sebaliknya, maka dapat diperkirakan lokasi tersebut memiliki anomali dengan adanya potensi panas bumi.

Berdasarkan peta NDVI Daerah Gunung Ciremai (Gambar 4), didapatkan nilai NDVI maksimum yaitu 0,87758 yang menunjukkan bahwa daerah ini memiliki vegetasi karena permukaan vegetasi akan lebih banyak memantulkan radiasi pada gelombang infrared dibanding dengan gelombang cahaya tampak. Nilai NDVI minimum yaitu $-0,747315$ yang menunjukkan bahwa daerah dengan nilai ini memiliki permukaan berupa air atau awan yang lebih banyak memantulkan gelombang cahaya tampak dibandingkan gelombang infrared.

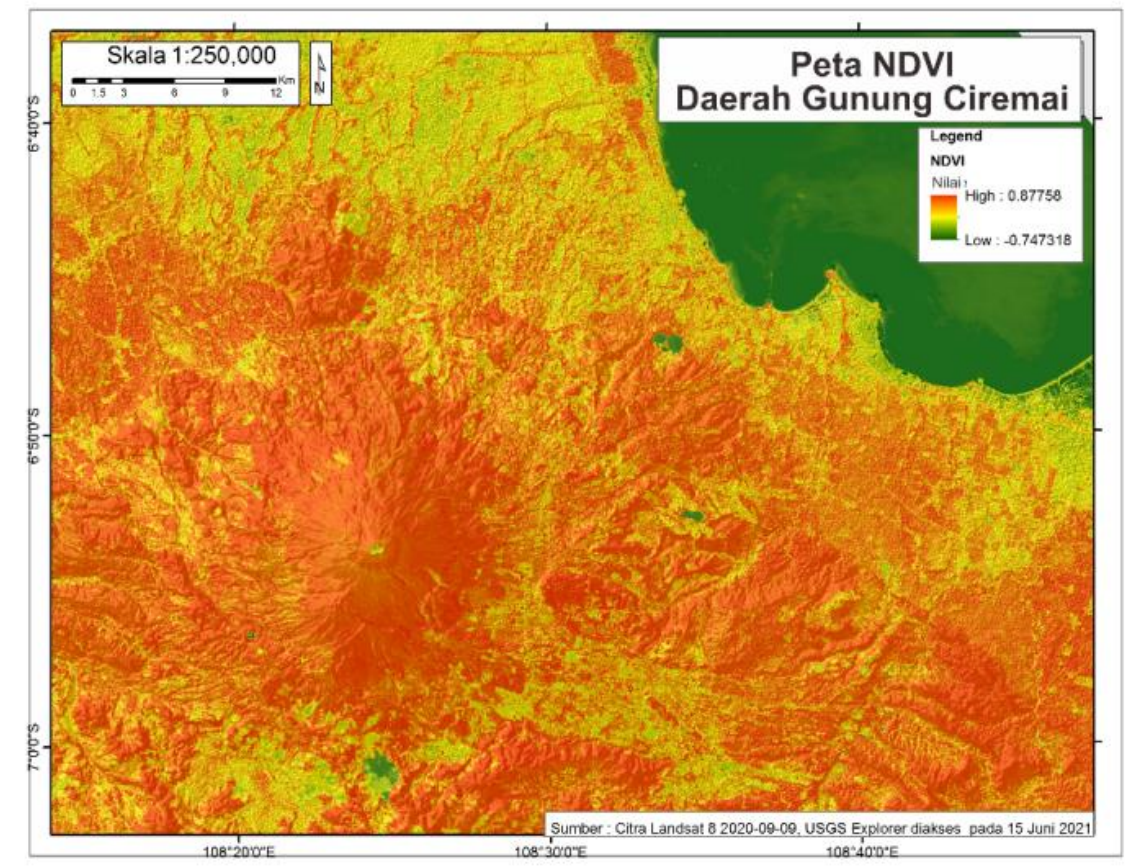

Gambar 4. Peta NDVI daerah Gunung Cermai 


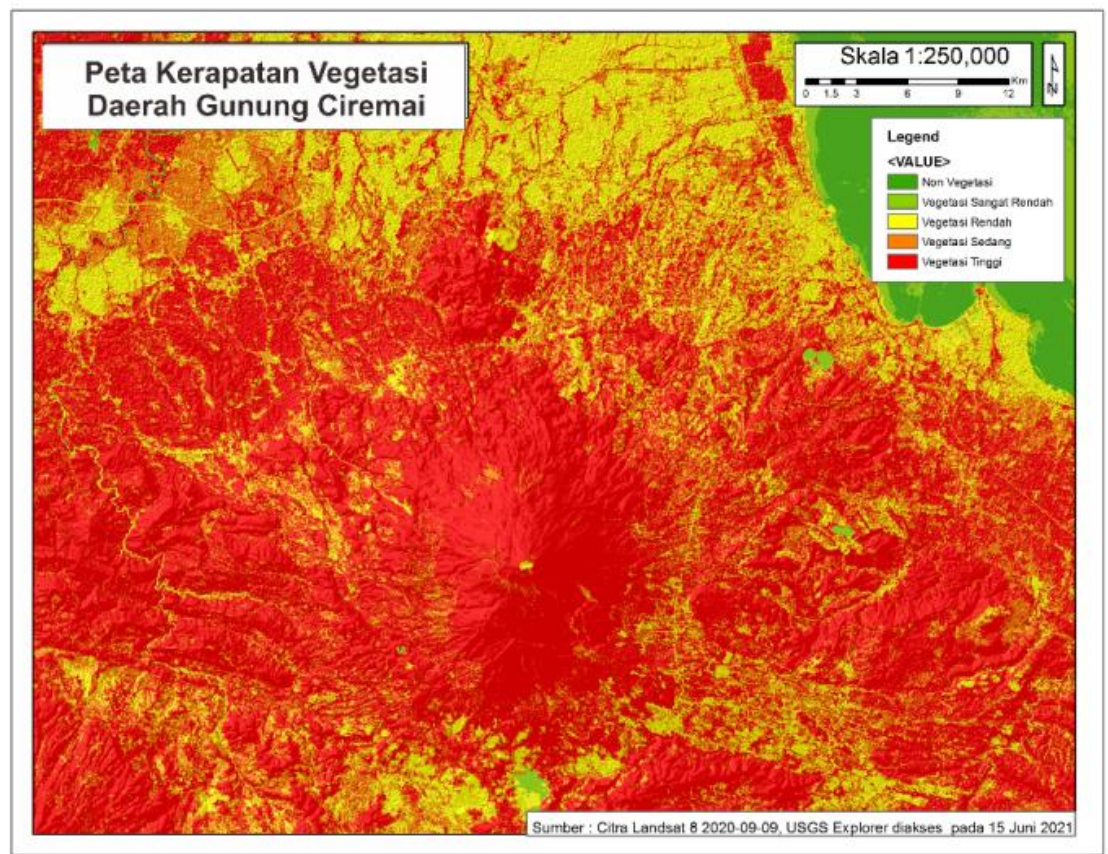

Gambar 5. Peta Kerapatan Vegetasi daerah Gunung Ciremai

Dari pengolahan NDVI ini maka didapatkan informasi mengenai persebaran vegetasi daerah Gunung Ciremai berdasarkan kerapatannya. Berdasarkan peta kerapatan vegetasi daerah Gunung Ciremai (Gambar 5), dapat diketahui bahwa daerah Gunung Ciremai dan sekitarnya didominasi oleh adanya vegetasi yang tinggi. Daerah dengan kerapatan vegetasi tinggi ditunjukkan dengan warna merah, daerah dengan kerapatan vegetasi sedang ditunjukkan dengan warna oranye, daerah dengan kerapatan vegetasi rendah ditunjukkan dengan warna kuning dan kerapatan vegetasi sangat rendah ditunjukkan dengan warna hijau muda. Dan daerah yang tidak memiliki vegetasi berupa air seperti waduk, danau, sungai, maupun laut ditunjukkan dengan warna hijau tua. Daerah dengan kerapatan vegetasi yang tinggi biasanya memiliki suhu permukaan yang rendah sehingga bila pada daerah tersebut terdeteksi adanya suhu permukaan yang tinggi maka dapat diindikasikan sebagai anomali akibat manifestasi panas bumi yang berada di bawah permukaan.

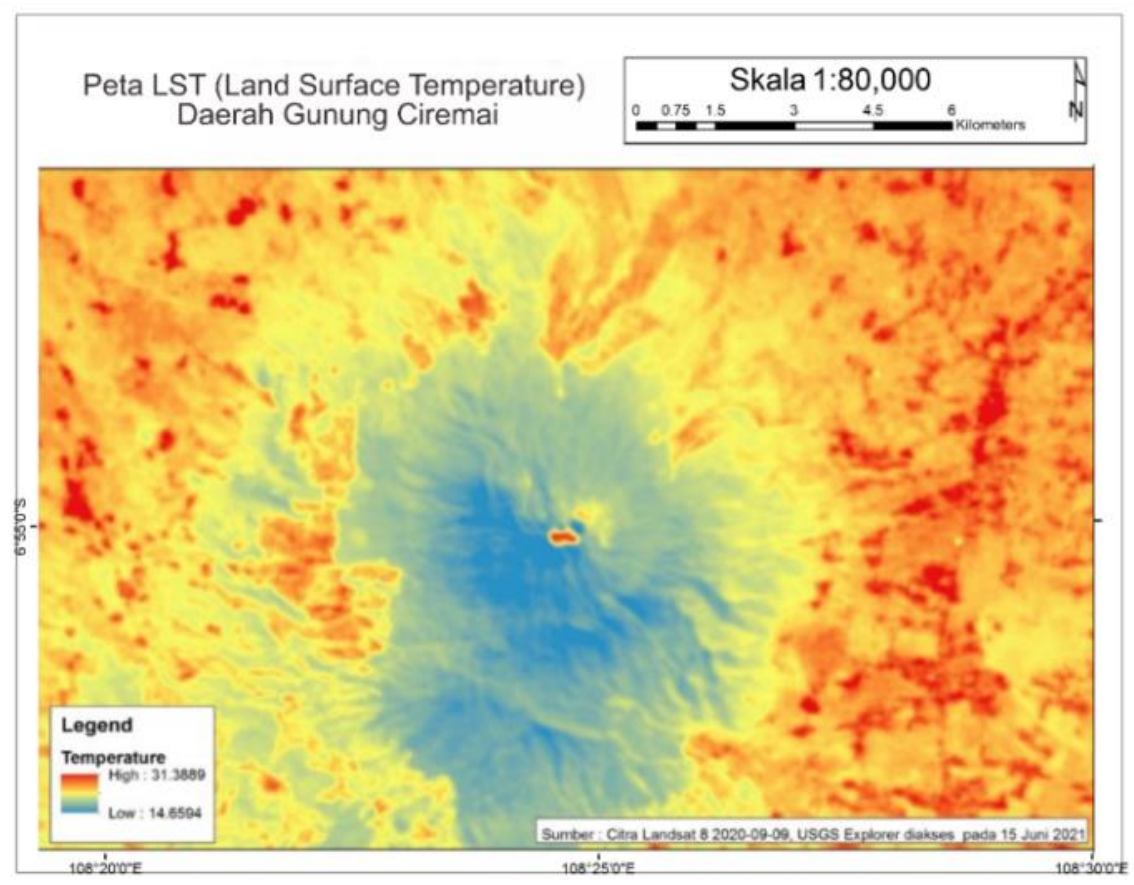

Gambar 6. Peta Land Surface Temperature (LST) daerah Gunung Ciremai dari data citra Landsat 8 


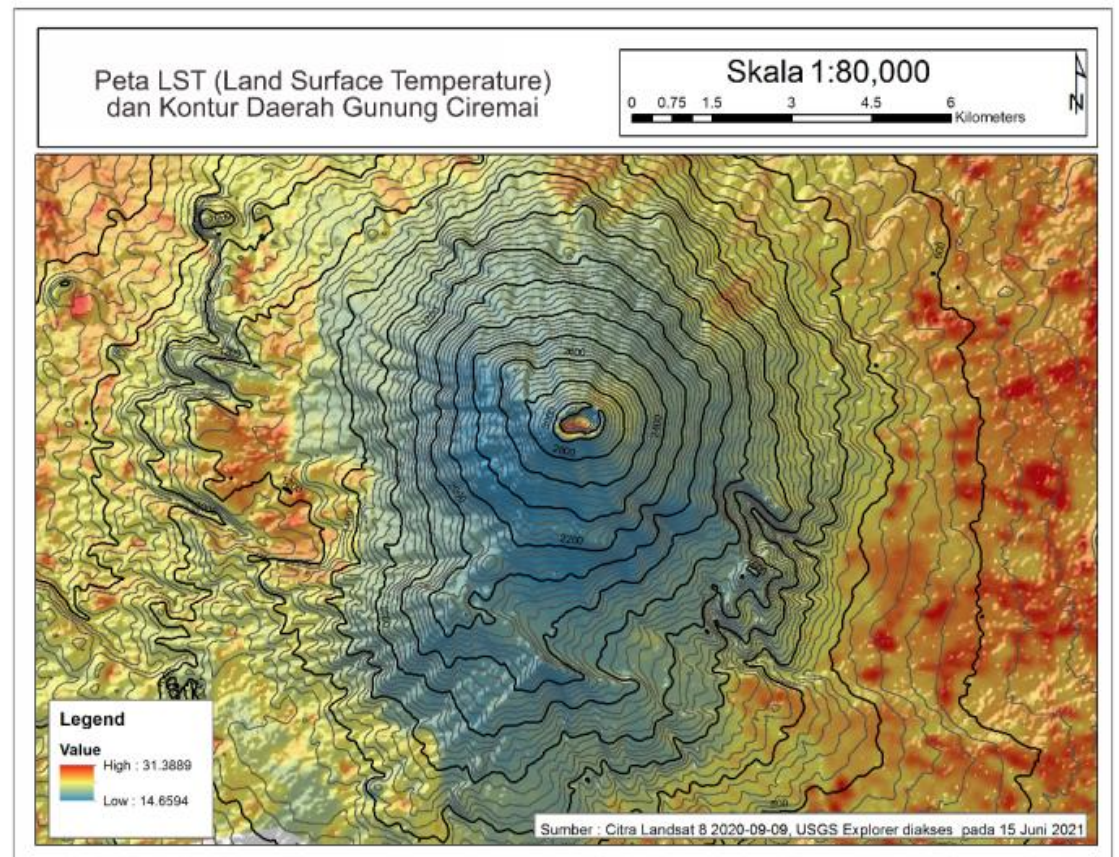

Gambar 7. Peta Land Surface Temperature (LST) beserta kontur daerah Gunung Ciremai

Berdasarkan pengolahan citra Landsat 8 tahun 2020 (Gambar 6 dan Gambar 7) di daerah Gunung Ciremai dan sekitarnya, dapat dianalisis bahwa suhu permukaan pada daerah tersebut memiliki nilai dalam rentang $15-31^{\circ} \mathrm{C}$. Persebaran tingkat LST rendah yaitu memiliki suhu sekitar $15^{\circ} \mathrm{C}$ yang ditunjukkan dengan warna biru tua hingga muda pada peta berada di lereng gunung Ciremai dekat dengan puncak Gunung. Hal ini merupakan pengaruh dari vegetasi dengan kerapatan tinggi berupa hutan. Untuk persebaran tingkat LST tinggi yaitu memiliki suhu sekitar $31^{\circ} \mathrm{C}$ yang ditunjukkan dengan warna merah pada peta berada di puncak Gunung Ciremai di ketinggian 3000 meter yang menunjukkan lokasi kawah dan timur laut hingga tenggara dari puncak Gunung Ciremai pada ketinggian 500 hingga 800 meter di atas permukaan laut. Area yang memiliki tingkat LST tinggi di antara tingkat LST yang rendah dapat diperkirakan sebagai area yang memiliki anomali. Hal ini bersesuaian dengan kerapatan vegetasi pada area tersebut yang tinggi sehingga seharusnya besar suhu permukaannya rendah bukan sebaliknya. Area anomali ini muncul akibat adanya manifestasi panas bumi di bawah permukaan yang mempengaruhi besar suhu di permukaannya. Manifestasi panas bumi inilah yang nantinya dapat digunakan sebagai tinjauan penentuan potensi panas bumi.

\section{KESIMPULAN}

Hasil penelitian menunjukkan bahwa area yang terindikasi memiliki manifestasi panas bumi di daerah Gunung Ciremai tersebar pada timur laut hingga tenggara dari puncak Gunung Ciremai yaitu pada Desa Sangkanurip dan Desa Pajambon, Kabupaten Kuningan, Jawa Barat. Nilai NDVI menunjukkan nilai sebesar 0,87758 hingga 0,747315 dimana nilai NDVI positif (+) menunjukkan adanya vegetasi dan nilai NDVI negatif (-) menunjukkan tidak adanya vegetasi. Berdasarkan Land Surface Temperature (LST), anomali panas bumi ini memiliki suhu sebesar $31^{\circ} \mathrm{C}$ di area dengan kerapatan vegetasi yang tinggi. Hal ini didukung dengan adanya sumber mata air panas yang telah dikelola pada kedua area tersebut.

\section{UCAPAN TERIMA KASIH}

Terima kasih kepada seluruh pihak yang terlibat dan mendukung dalam pembuatan artikel ini. Terima kasih kepada dosen pembimbing yang telah mengajarkan, mengarahkan, serta membimbing dalam penyelesaian penulisan artikel ini.

\section{DAFTAR PUSTAKA}

Faridah, S. A., \& Krisbiantoro, A. (2014). Analisis Distribusi Temperatur Permukaan Tanah Wilayah Potensi Panas Bumi Menggunakan Teknik Penginderaan Jauh di Gunung Lamongan, Tiris-Probolinggo, Jawa Timur. Berkala Fisika, 17(2), 67-72.

Avdan, U., \& Jovanovska, G. (2016). Algorithm for Automated Mapping of Land Surface Temperature Using Landsat 8 Satellite Data. Journal of Sensors, 2016, https://doi.org/10.1155/2016/1480307

Candra, R., \& Santi, N. (2011). Teknik Perbaikan Kualitas Citra Satelit Cuaca dengan Sataid. Jurnal Teknologi Informasi DINAMIK, 16(2), 101-109.

Darmawan, I. G. B., Yassar, M. F., Elvarani, A. Y., Vira, B. A., \& Damayanti, L. (2020). Preliminary Study of Mining Material Prospects Based on Hydrothermal Alteration Distribution Using Composite and Density Slicing of Landsat 8 Image in Ulubongka Regency, Central Sulawesi. PROMINE, 8(1), 1-7. DOI: https://doi.org/10.23960/igrs.2021.v2i2.64 
Dianovita, \& Mahendra, R. (2014). Kajian Ketelitian Geometri Citra Landsat 8 Level 1T. Seminar Nasional Penginderaan Jauh, 254-260.

Farras, N., Sukmono, A., \& Bashit, N. (2017). Analisis Estimasi Energi Panas Bumi Menggunakan Citra Landsat 8 (Studi Kasus: Kawasan Gunung Telomoyo). Jurnal Geodesi Undip, 6(4), 371-380.

Gemitzi, A., Dalampakis, P., \& Falalakis, G. (2021). Detecting geothermal anomalies using Landsat 8 thermal infrared remotely sensed data. International Journal of Applied Earth Observation and Geoinformation, 96, 02283. https://doi.org/10.1016/j.jag.2020.102283

Agung, B. H., Faizal, A., Anggi, A., Bahri, A. S., \& Utama, W. (2013). Aplikasi Citra Satelit Landsat 8 Untuk Identifikasi Daerah Prospek Panas Bumi Daerah Songgoriti Batu dan Sekitarnya. Jurnal Geosaintek, 3(3), 149-154.

Kusumadinata, K. (1971). Gunung Tjiremai, kumpulan data mentah hingga bulan April 1971. Direktorat Geologi, ESDM.

Pratomo, I. (2008). Kegiatan Gunungapi Ciremai Jawa Barat dan Pengaruhnya Terhadap Lingkungan di Sekitarnya. Jurnal Biologi Indonesia, 4(5), 261-278.

Samodra, H. (2008). Geologi Batuan Dasar Gunung Ciremai Jawa barat. Jurnal Biologi Indonesia, 4(5), 279-287.
Sitanggang, G. (2013). Kajian Pemanfaatan Satelit Masa Depan: Sistem Penginderaan Jauh Satelit LDCM (Landsat-8). Berita Dirgantara LAPAN, 11(2), 47-58.

Situmorang, T., Hadisantono, R. D., \& Asmoro, P. (1995). Peta Geologi Guningapi Cereme, Jawa Barat. Direktorat Vulkanologi, ESDM.

Skoković, D., Sobrino, J. A., Jiménez-Muñoz, J. C., Sòria, G., Julien, Y., Mattar, C., \& Cristóbal, J. (2014). Calibration and Validation of land surface temperature for Landsat8- TIRS sensor. In LPVE (Land Product Vaidation and Evolutian, ESA/ESRIN Frascati, 87(8), 44874497), https://doi.org/10.1063/1.452862.

Sukendar, P. M., Sasmito, B., \& Wijaya, A. P. (2016). Analisis Sebaran Kawasan Potensial Panas Bumi Gunung Salak Dengan Suhu Permukaan, Indeks Vegetasi Dan Geomorfologl. Jurnal Geodesi Undip, 5(2), 66-75.

Supriatna, W., \& Sukartono. (2002). Teknik Perbaikan Data Digital (Koreksi Dan Penajaman) Citra Satelit. Buletin Teknik Pertanian, 7(1), 4-6.

Undang-Undang Republik Indonesia Nomor 21 Tahun 2014 Tentang Panas Bumi. (2014). https://peraturan.bpk.go.id/Home/Details/386 84 (diakses 1 Agustus 2021 pukul 19.17 WIB). 